\title{
PRAKIRAAN DAMPAK ANCAMAN DAN GANGGUAN DALAM PERIKANAN TANGKAP DAN PENGAWASAN SUMBERDAYA KELAUTAN DAN PERIKANAN
}

\section{Threat and Interference Impact Forecasting in Capture Fisheries and Marine and Fisheries Resources Monitoring}

\author{
Zahri Nasution dan Armen Zulham \\ Balai Besar Penelitian Sosial Ekonomi Kelautan dan Perikanan \\ JI. KS. Tubun Petamburan VI Jakarta 10260 \\ Telp. (021) 53650162, Fax. (021)53650159 \\ Email: zahri_nas@yahoo.com \\ Diterima 14 Maret 2013 - Disetujui 31 Mei 2013
}

\begin{abstract}
ABSTRAK
Ancaman dan gangguan dalam pembangunan perikanan tangkap dan pengawasan sumber daya kelautan dan perikanan perlu diantisipasi guna mencapai manfaat sumber daya perikanan secara tepat bagi masyarakat nelayan. Studi ini bertujuan mengidentifikasi dan menganalisis prakiraan dampak keamanan (AMDAK) pada setiap program perikanan tangkap dan pengawasan sumber daya kelautan dan perikanan pada Kementerian Kelautan dan Perikanan (KKP). Kajian ini menggunakan pendekatan kualitatif. Jenis data yang digunakan dalam kegiatan ini adalah data sekunder dan data primer. Data yang didapat diolah dan dianalisis secara deskriptif serta diinterpretasikan secara logis. Hasil studi menunjukkan bahwa pada kegiatan yang tercakup dalam program pengembangan dan pengelolaan perikanan tangkap terdapat potensi gangguan dan ancaman faktual mulai dari konflik antar kelompok masyarakat hingga gangguan dari adanya kapal asing. Disamping itu, terdapat pula potensi konflik penggunaan alat tangkap antar nelayan dan gangguan kapal asing. Luasnya wilayah perairan yang dimiliki Indonesia dan keterbatasan sumber daya manusia dan pengawasnya, menyebabkan masih banyaknya terjadi pelanggaran dalam pemanfaatan sumber daya perikanan. Pengawasan secara terpadu dapat memberikan dampak positif dalam meningkatkan perekonomian, karena porsi kekayaan sumber daya perikanan tidak berkurang akibat adanya kegiatan penangkapan ikan yang illegal.
\end{abstract}

Kata Kunci: prakiraan dampak, ganggun, perikanan tangkap, pengawasan sumber daya kelautan dan perikanan

\begin{abstract}
Threats and disruptions in fisheries development and marine and fisheries resources monitoring are necessary to be anticipated toachieve appropriate benefits of fishery resources to fisher. This study aimed to identify and analyze security impact forecasts (AMDAK) on each program and surveillance of fisheries resources and marine fisheries in the Ministry of Marine Affairs and Fisheries (MMAF). This study used a qualitative approach. Types of datas used in this activity are secondary data and primary data. Data obtained were processed and analyzed descriptively and logically interpreted. The study results showed that the activities included in the program of development and capture fisheries management was potentialy for interference and threats factual conflicts ranging from community groups to interference from the presence of foreign vessels. In addition, there are potential conflicts between fishers, fishing gears and interference of foreign vessels. The wide of territorial waters were owned by Indonesia and human resource limitations and a supervisor, causing still many violations in the utilization of fisheries resources. Integrated surveillancecan provide a positive impact to the economy, because the portion of the fishery resource wealth is not reduced as a result of illegal fishing activities.
\end{abstract}

Keywords: impact forecasting, disruption, capture fisheries, marine and fisheries resources surveillance 


\section{PENDAHULUAN}

POLRI sebagai penyelengara keamanan dalam negeri, termasuk di tingkat perairan memiliki tugas dan fungsi memelihara keamanan dan ketertiban masyarakat (kamtibmas), penegakan hukum serta memberikan perlindungan, pengayoman dan pelayanan kepada masyarakat, harus mampu memprediksi dan mengantisipasi berbagai bentuk ancaman dan gangguan keamanan yang mungkin timbul (POLRI, 2010). Terkait hal ini, Polri memiliki konsep pengamanan yang proaktif dan integratif, bukan reaktif, yaitu konsep pengamanan yang tidak hanya dilakukan pada saat terjadinya gangguan kamtibmas, tetapi sejak awal perencanaan pembangunan sudah terkonsep secara integral dan menyeluruh. Konsep tersebut termasuk kebijakan dan strategi Polri di bidang Penegakan Hukum dan Pembinaan Keamanan yang kesemuanya merupakan salah satu agenda Rencana Pembangunan Jangka Menengah Nasional 2010-2014.

Dalam mendukung agenda Rencana Pembangunan Jangka Menengah Nasional di bidang Penegakan Hukum dan Pembinaan Keamanan di sektor kelautan dan perikanan, maka diperlukan identifikasi dan analisis mengenai dampak keamanan yang diperkirakan akan terjadi pada sektor kelautan dan perikanan. Hasil ini nantinya diperkirakan dapat digunakan sebagai langkah awal menentukan kebutuhan penegakan hukum dan pembinaan keamanan pada sektor kelautan dan perikanan. Dengan demikian, diharapkan ancaman dan gangguan yang akan terjadi pada proses pembangunan kelautan dan perikanan dapat diperkecil atau dihilangkan sama sekali.

Pentingnya analisis masalah prakiraan dampak (Amdak) keamanan di sektor kelautan dan perikanan ini sesuai pula dengan Tujuan Rencana Pembangunan Jangka Menengah Nasional (RPJMN) 2010-2014 yang diarahkan untuk memantapkan penataan kembali Indonesia di segala bidang dengan menekankan pada upaya peningkatan kualitas sumberdaya manusia termasuk pengembangan kemampuan iptek serta penguatan daya saing perekonomian. Penguatan daya saing perekonomian inilah yang terkait secara langsung dengan pembangunan kelautan dan sumberdaya alam lainnya sesuai dengan potensi daerah secara terpadu serta meningkatnya pengembangan ilmu pengetahuan dan teknologi (KKP, 2010).
Penelitian ini bertujuan mengidentifikasi dan menganalisis prakiraan dampak keamanan pada setiap program perikanan tangkap dan pengawasan sumber daya kelautan dan perikanan pada Kementerian Kelautan dan Perikanan (KKP). Berdasarkan analisis tersebut kemudian disusun rekomendasi kebijakan yang diperlukan dalam mengatasi prakiraan dampak keamanan tersebut.

\section{METODOLOGI}

Kajian ini merupakan suatu analisis kebijakan, yaitu suatu analisis dan sintesa yang menghasilkan dan menyajikan informasi dapat memberi landasan bagi para pembuat kebijakan dalam membuat keputusan (Dunn, 2000). Dengan kata lain, proses atau kegiatan mensintesa informasi dari berbagai sumber, termasuk hasil-hasil penelitian, untuk menghasilkan rekomendasi opsi desain kebijakan publik (Simatupang, 2003). Hal ini didasarkan pertimbangan bahwa bidang penegakan hukum dan pembinaan keamanan merupakan bagian penting yang tidak terpisahkan dalam rangka mencapai tujuan pembangunan kelautan dan perikanan.

Kajian ini menggunakan pendekatan kualitatif, khususnya untuk menemukan prakiraan mengenai dampak keamanan di sektor kelautan dan perikanan. Setelah dampak teridentifikasi melalui prakiraan ahli (expert judgement), hasil tersebut kemudian didiskusikan diantara tim peneliti. Hasil diskusi itulah yang merupakan bahan dasar untuk membuat laporan kegiatan ini.

Jenis data yang digunakan dalam kegiatan ini adalah data sekunder. Data sekunder dikumpulkan meliputi berbagai laporan penelitian dan atau kajian terhadap sektor kelautan dan perikanan terutama Rencara Straegis Kementerian Kelautan dan Perikanan (KKP), dan Laporan Tahunan masing-masing direktorat jenderal di lingkup KKP yang berkaitan dengan perikanan tangkap dan pengawasan sumber daya kelautan dan perikanan. Data yang didapat diolah dan dianalisis secara deskriptif serta diinterpretasikan secara logis (Nazir, 1988).

\section{PENGEMBANGAN DAN PENGELOLAAN PERIKANAN TANGKAP}

Rencana kegiatan yang terkait dengan program pengembangan dan pengelolaan perikanan tangkap yang menjadi tugas pokok dan 
fungsi dari Direktorat Jenderal Perikanan Tangkap (DJPT) untuk tahun 2010-2014 adalah pengelolaan sumberdaya ikan, yang meliputi: pembinaan dan pengembangan kapalperikanan, alat penangkap ikan dan pengawakan kapal perikanan,dan pengembangan pembangunan dan pengelolaan pelabuhan perikanan, pelayanan usaha perikanan tangkap yang efisien, tertib dan berkelanjutan, serta pengembangan usaha penangkapan ikan dan pemberdayaan nelayan skala kecil. Keterkaitan antara rencana kegiatan masing-masing terhadap prakiraan masalah dampak keamanan (Amdak) diperlihatkan pada Tabel 1.

Tabel 1 menunjukkan bahwa dari keseluruhan kegiatan yang tercakup dalam program pengembangan dan pengelolaan perikanan tangkap terdapat potensi gangguan dan ancaman faktual mulai dari konflik antar kelompok masyarakat hingga gangguan dari adanya kapal

Tabel 1. Prakiraan Potensi Kerawanan / Gangguan dan Ancaman Faktual Keamanan pada Kegiatan yang Tercakup Dalam Program Pengembangan dan Pengelolaan Perikanan Tangkap KKP 2010-2014.

Table 1. Forecasting on Potential Vulnerability/Disturbance and Factual Security Threats for Activity that Inherent with Program of Development and Capture Fisheries Management, MMF Year 2010-2014.

\begin{tabular}{|c|c|c|c|}
\hline No & $\begin{array}{c}\text { Rencana Kegiatan/ } \\
\text { Actvities Plan }\end{array}$ & $\begin{array}{l}\text { Potensi Kerawanan } \\
\text { Gangguan/ } \\
\text { Vulnerability } \\
\text { Disturbance Potency }\end{array}$ & $\begin{array}{l}\text { Ancaman Faktual (AF) } \\
\text { Keamanan/ } \\
\text { Factual Security Threats }\end{array}$ \\
\hline 1 & $\begin{array}{l}\text { Pengelolaan sumberdaya } \\
\text { ikan/ Fisheries Resources } \\
\text { Management }\end{array}$ & $\begin{array}{l}\text { batas wilayah antar } \\
\text { negara dan antar } \\
\text { kabupaten (otonomi } \\
\text { daerah)/ boundaries } \\
\text { between state and } \\
\text { inter-district (regional } \\
\text { autonomy) }\end{array}$ & $\begin{array}{l}\text { Potensi konflik antar kelompok } \\
\text { masyarakat dan pelanggaran } \\
\text { batas wilayah/ Potential conflicts } \\
\text { between communities and } \\
\text { boundary violations }\end{array}$ \\
\hline 2 & $\begin{array}{l}\text { Pembinaan, dan } \\
\text { pengembangan kapal } \\
\text { perikanan, alat penangkap } \\
\text { ikan, dan pengawakan kapal } \\
\text { perikanan/ Guidance, and } \\
\text { development fishing vessels, } \\
\text { fishing gear, and manning of } \\
\text { fishing vessels }\end{array}$ & $\begin{array}{l}\text { Gangguan kapal asing } \\
\text { yang illegal fishing } \\
\text { dan gangguan cuaca } \\
\text { buruk/ Disturbance of } \\
\text { foreign vessels of illegal } \\
\text { fishing and bad weather } \\
\text { disturbances }\end{array}$ & $\begin{array}{l}\text { Potensi konflik penggunaan alat } \\
\text { tangkap dan gangguan kapal } \\
\text { asing serta potensi timbulnya } \\
\text { kecelakaan laut/ Potential } \\
\text { conflicts of fishing gears and } \\
\text { interference of foreign vessels as } \\
\text { well as the potential for marine } \\
\text { accidents }\end{array}$ \\
\hline 3 & $\begin{array}{l}\text { Pengembangan Pembangunan } \\
\text { dan pengelolaan pelabuhan } \\
\text { perikanan/ Development and } \\
\text { management of fishing ports }\end{array}$ & $\begin{array}{l}\text { Gangguan cuaca yang } \\
\text { buruk/ Bad weather } \\
\text { disruption? }\end{array}$ & $\begin{array}{l}\text { Potensi konflik kepentingan } \\
\text { pemerintah dan pemerintah } \\
\text { daerah/ Potential conflicts of } \\
\text { interest and local governments }\end{array}$ \\
\hline 4 & $\begin{array}{l}\text { Pelayanan usaha perikanan } \\
\text { tangkap yang efisien, tertib, dan } \\
\text { berkelanjutan/ Fishery business } \\
\text { services that are efficient, } \\
\text { orderly, and sustainable }\end{array}$ & $\begin{array}{l}\text { Penggunaan izin oleh } \\
\text { kapal asing secara } \\
\text { illegal/ The use permit } \\
\text { by foreign vessel } \\
\text { illegally }\end{array}$ & $\begin{array}{l}\text { Ancaman keamanan dari kapal } \\
\text { asing/ Security threats from } \\
\text { foreign vessel }\end{array}$ \\
\hline 5 & $\begin{array}{l}\text { Pengembangan usaha } \\
\text { penangkapan ikan dan } \\
\text { pemberdayaan nelayan skala } \\
\text { kecil/ Development of Fishing } \\
\text { business and empowerment of } \\
\text { small-scale fisher }\end{array}$ & $\begin{array}{l}\text { Potensi konflik } \\
\text { penggunaan alat } \\
\text { tangkap/ Potential } \\
\text { conflicts of fishing gears }\end{array}$ & $\begin{array}{l}\text { Potensi konflik antar kelompok } \\
\text { masyarakat nelayan/ Potential } \\
\text { conflicts between the fishing } \\
\text { communities }\end{array}$ \\
\hline
\end{tabular}

Sumber: diolah dari berbagai informasi dan pendapat.

Source : processed from various of information and opinions 
asing. Secara rinci prakiraan masalah dampak keamanan (Amdak) mulai aspek demografi hingga aspek transportasi dikemukakan pada Lampiran 1.

Berdasarkan tabel Lampiran 1 pada baris pertama dapat dilihat bahwa ancaman faktual keamanan dari kegiatan pengelolaan sumberdaya ikan adalah adanya potensi konflik antar kelompok masyarakat dan pelanggaran batas wilayah. Potensi konflik pada kegiatan pengelolaan sumberdaya ikan tersebut dapat terjadi antar masyarakat di kabupaten yang berbedadalam satu wilayah propinsi, ataupun antar wilayah pengelolaan perikanan yang satu dengan yang lainnya. Adapun pelanggaran batas wilayah utamanya terjadi antar negara dan antar kabupaten atau propinsi, yang menjadi potensi kerawanan atau gangguan.

Dilihat dari aspek demografi, tampak bahwa akan ada kemungkinan terganggunya ketertiban masyarakat dalam melaksanakan penangkapan ikan. Selain itu juga terdapat kemungkinan pelanggaran batas wilayah penangkapan antar propinsi atau kabupaten, yang selanjutnya dapat memicu adanya potensi konflik antar masyarakat antar wilayah penangkapan ikan. Dilihat Dari aspek ekonomi, dengan adanya wilayah pengelolaan perikanan yang jauh dari pusat perkotaan dan atau pusat kegiatan pemasaran, maka kemungkinan besar terjadinya sistem ekonomi ijon antara pemilik modal dan nelayan yang melaksanakan penangkapan ikan.

Dilihat dari segi budaya, pembentukan wilayah pengelolaan perikanan yang diprakarsai pemerintah dapat merubah tradisi pengelolaan ikan yang sudahada dan melembaga dalam masyarakat. Hal ini dari segi ideologi akan dapat mengakibatkan semakin memudarnya kearifan masyarakat lokal yang selama ini mereka patuhi. Dalam aspek politik, terlihat bahwa dengan adanya wilayah pengelolaan perikanan ini,menunjukkan bahwa ada "political will" dari pemerintah dalammengelola sumberdaya ikan yang tidak lain sasarannya adalah mensejahterakan masyarakat nelayan. Oleh karena itu, sudah saatnya ada keberpihakan peraturan pengelolaan perikanan terhadap masyarakat nelayan. Meskipun demikian, dari aspek pertahanan, adanya wilayah pengelolaan perikanan ini ada potensi pelanggaran terhadap batas wilayah Negara Kesatuan Republik Indonesia (NKRI). Sementara dari aspek lingkungan,mungkin saja terjadi kerusakan ekosistem pesisir dan laut jika pemerintah kurang memberi perhatian dalam pengendalian batas wilayah penangkapan ikan.
Pada Lampiran 1 pada baris kedua menunjukkan bahwa ancaman faktual keamanan dari kegiatan pembinaan dan pengembangan kapalperikanan, alat tangkap ikan, dan pengawakan kapal perikanan adalah adanya potensi konflik penggunaan alat tangkap dan gangguan kapal asing. Potensi konflik pada kegiatan ini dapat saja terjadi baik antar kelompok masyarakat dalam satu wilayah propinsi atau kabupaten, ataupun antar wilayah pengelolaan perikanan yang satu dengan yang lainnya. Adapun gangguan kapalasing kemungkinan terjadi antar batas wilayah negara, disamping antar batas kabupaten atau propinsi. Gangguan lainnya yang mungkin terjadi adalah kondisi cuaca yang buruk.

Dilihat, dari aspek demografi, akan ada kemungkinan terjadinya kurang tertibnya tonase kapal dan penggunaan alat tangkap yang melanggar aturan yang berlaku. Sementara dari segi ekonomi, dengan panjangnya birokrasi dan banyaknya izin yang harus dikantongi oleh sebuah kapal, maka kemungkinan akan terjadi ekonomi biaya tinggi terkait dengan penangkapan dan alat tangkap yang dilakukan oleh masyarakat nelayan. Dalam hal ini, pembinaan dan pengembangan kapal perikanan, alat tangkap ikan dan pengawakan kapal perikanan kadang-kadang secara sosialada penolakan dari nelayan terhadap ketentuan yang diberlakukan. Hal ini, juga berkaitan dengan kuatnya tradisi masyarakat terhadap tata cara penangkapan ikan. Pada gilirannya, hal tersebut akan berpengaruh secara ideologi, yaitu pudarnya kearifan masyarakat lokal.

Dalam aspek politik, terkait dengan pembinaan dan pengembangan kapal perikanan dan alat tangkap ikan terlihat juga kurangnya otorisasi pemerintah terhadap pemerintah daerah. Akibatnya, secara hukum akan banyak pelanggaran tonase kapal, serta penggunaan alat tangkap yang tidak sesuai dengan izin yang didapatkan oleh masyarakat nelayan. Lebih lanjut, dari aspek lingkungan dapat diduga akan terjadi pencemaran pada ekosistem pesisir dan laut.

Pada Lampiran 1 pada baris ketiga menunjukkan bahwa ancaman faktual keamanan dari kegiatan pengembangan pembangunan dan pengelolaan pelabuhan perikanan adalah adanya potensi konflik kepentingan antara pemerintah pusat dan pemerintah daerah, disamping kerawanan yang diakibatkan oleh gangguan cuaca buruk. Konflik kepentingan dalam hal ini dapat bermuara pada terdapatnya beberapa 
pungutan bagi nelayan, baik yang dilakukan oleh pemerintah propinsi maupun kabupaten. Padahal keberadaan pelabuhan perikanan diharapkan agar dapat menertibkan kegiatan masyarakat nelayan dan pengolah. Sebagai contoh pembangunan dan pengembangan pelabuhan perikanan diharapkan akan mengakibatkan peningkatan persaingan harga jual ikan hasil tangkapan nelayan, sehingga pendapatan mereka bertambah.

Di lain pihak, dari aspek budaya ada kemungkinan kuatnya ikatan patrón klien yang terjadi pada masyarakat nelayan dan pemilik modal dan atau pedagang ikan yang ada di wilayah tersebut. Akibatnya, tidak jarang terjadi penolakan dari masyarakat terhadap ketentuan-ketentuan yang diberlakukan oleh pelabuhan perikanan. Tambahan pula, kuatnya ikatan kekerabatan dalam beberapa kelompok masyarakat mengakibatkan masyarakat merasa tidak terbiasa dengan tempat mendarat yang baru yang berada di pelabuhan perikanan.

Konflik kepentingan yang terjadi antara pemerintah dan pemerintah daerah juga mengakibatkan banyaknya pelanggaran tonase kapal yang tidak sesuai dengan surat izin yang dimiliki oleh nelayan. Disamping itu, dapat pula terjadi pencemaran terhadap ekosistem pesisir dan laut dengan banyak kapal perikanan yang mencuci kapalnya dengan membuang air limbahnya langsung ke laut, yang kadang-kadang dibarengi pula dengan gangguan cuaca yang buruk.

Pada Lampiran 1 baris keempat terlihat bahwa pada kegiatan pelayanan usaha perikanan tangkap yang efisien, tertib dan berkelanjutan ada ancaman faktual keamanan berupa gangguan dan ancaman dari kapal asing yang beroperasi menggunakan izin kapal perikanan perikanan Indonesia (penyalahgunaan izin penangkapan ikan oleh kapal asing). Padahal secara demografi diharapkan akan terjadi ketertiban dalam penggunaan alat tangkap, sehingga tidak terjadi ekonomi biaya tinggi dalam usaha penangkapan ikan. Dari aspek budaya, kuatnya tradisi masyarakat terhadap tata cara penangkapan ikan dapat mengakibatkan adanya penolakan dari nelayan terhadap ketentuan yang diberlakukan terkait izin usaha penangkapan ikan. Seandainya tidak ada penolakan dari nelayan, dari aspek ideologi juga dapat mengakibatkan pudarnya kearifan lokal yang ada pada masyarakat nelayan.
Kurangnya otorisasi pemerintah terhadap pemerintah daerah dapat terjadi akibat kuatnya pemberlakuan otonomidaerah, sehingga bukan tidak mungkin juga akan terjadi banyaknya pelanggaran tonase kapal, dan penggunaan alat tangkap yang tidak sesuai dengan izinnya. Kemudian, yang tidak kalah pentingnya adalah ada pula kemungkinan terjadinya pencemaran terhadap ekosistem pesisir dan laut sebagai akibat tindakan membuang limbah hasil pencucian kapal di laut, baik berupa oli atau solar.

Pada Lampiran 1 baris kelima, dalam kegiatan pengembangan usaha penangkapan ikan dan pemberdayaan nelayan skala kecil dapat muncul ancaman keamanan berupa konflik penggunaan alat tangkap antar nelayan misalnya berupa penggunaan rumpon oleh nelayan yang bukan pemiliknya, pada saat pemiliknya tidak ada atau sedang menuju pelabuhan perikanan untuk menjualikan hasil tangkapannya. Padahal, kegiatan ini, terutama pemberdayaan nelayan skala kecil pada prinsipnya ingin mengurangi persaingan usaha antar nelayan dalam melaksanakan penangkapan ikan, sehingga berkurangnya persaingan dalam memproduksi ikan yang berasal dari hasil tangkapan di laut.

Dilihat dari aspek budaya, kuatnya tradisi masyarakat terhadap tata cara penangkapan ikan yang dilakukan secara tradisional secara turuntemurun dapat mengakibatkan penolakan nelayan terhadap upaya pemberdayaan yang dilakukan terhadap mereka. Kalaupun tidak ada penolakan nelayan maka dari aspek ideologi juga dapat berakibat pada memudarnya kearifan lokal yang ada.

\section{PENGAWASAN SUMBER DAYA KELAUTAN DAN PERIKANAN}

Pengawasan Sumber Daya Kelautan dan Perikanan merupakan program Direktorat Jenderal Pengawasan dan Pengendalian Sumber Daya Kelautan dan Perikanan dalam rentang tahun 2010 sampai tahun 2014. Program tersebut meliputi beberapa kegiatan, yaitu peningkatan operasional pengawasan sumber daya perikanan, peningkatan operasional pengawasan sumberdaya kelautan, peningkatan operasional dan pemeliharaan kapal pengawas, pengembangan sarana dan prasarana pengawasan dan pemantauan kapal perikanan, dan penyelesaian tindak pidana kelautan dan perikanan. Setiap kegiatan tersebut memiliki 
dampak yang berpotensi menggangu keamanan (Tabel 2).

Tabel 2 menunjukkan bahwa potensi dampak kerawan gangguan juga dapat disebabkan masuknya kapal asing ke dalam wilayah NKRI tanpa ijin untuk mengambil sumber daya perikanan.Masuknya kapal asing ini menyebabkan adanya pelanggaran terhadap geografi laut Indonesia yang dapat menyebabkan hubungan dengan negara kapal asing di bidang pertahanan menjadi kurang baik. Hubungan yang kurang baik tersebut dapat diredam dengan kekuatan politik dalam melakukan negoisasi mencari jalan damai. Banyaknya kapal asing yang masuk wilayah NKRI, berpotensi juga menyebabkan adanya pencemaran lingkungan. Kondisi tersebut disebabkan adanya sisa tumpahan bahan bakar kapal maupun limbah sampah yang dibuang di perairan laut.

Tabel 2. Prakiraan Potensi Kerawanan/ Gangguan dan Ancaman Faktual Keamanan pada Kegiatan yang Tercakup Dalam Program Pengawasan Sumber Daya Kelautan dan Perikanan KKP 2010-2014.

Table 2. Forecasting on Potential Vulnerability / Disturbance and Factual Security Threats in the Activity that Inherent In Marine and Fisheries Resources Surveillance Program, MMF Year 2010-2014.

\begin{tabular}{|c|c|c|c|}
\hline No. & $\begin{array}{c}\text { Rencana Kegiatan/ } \\
\text { Actvities Plan }\end{array}$ & $\begin{array}{c}\text { Potensi Kerawanan } \\
\text { Gangguan/ Vulnerability } \\
\text { Disturbance Potency }\end{array}$ & $\begin{array}{c}\text { Ancaman Faktual (AF) } \\
\text { Keamanan/ Factual Security } \\
\text { Threats }\end{array}$ \\
\hline 1 & $\begin{array}{l}\text { Peningkatan Operasional } \\
\text { Pengawasan Sumber Daya } \\
\text { Perikanan/ Imporovement } \\
\text { of Operational Fisheries } \\
\text { Resources Surveillance }\end{array}$ & $\begin{array}{l}\text { Banyaknya kapal asing } \\
\text { yang masuk ke perairan } \\
\text { NKRI tanpa ijin/ The number } \\
\text { of foreign vessels that enter } \\
\text { the Indonesian waters } \\
\text { without permission }\end{array}$ & $\begin{array}{l}\text { Pencurian hasil sumber daya } \\
\text { perikanan/ Stealing of fisheries } \\
\text { resources }\end{array}$ \\
\hline 2 & $\begin{array}{l}\text { Peningkatan Operasional } \\
\text { Pengawasan Sumber Daya } \\
\text { Kelautan/ Imporovement of } \\
\text { Operational Marine Resources } \\
\text { Surveillance }\end{array}$ & $\begin{array}{l}\text { Banyaknya kapal asing } \\
\text { yang masuk ke perairan } \\
\text { NKRI tanpa ijin/ The number } \\
\text { of foreign vessels that enter } \\
\text { the Indonesian waters } \\
\text { without permission }\end{array}$ & $\begin{array}{l}\text { Pelanggaran batas wilayah } \\
\text { oleh kapal asing/ Boundary } \\
\text { violations by foreign vessels }\end{array}$ \\
\hline 3 & $\begin{array}{l}\text { Peningkatan Operasional } \\
\text { \& Pemeliharaan Kapal } \\
\text { Pengawas/ Improvement of } \\
\text { Operational \& Maintenance } \\
\text { Surveillance Vessels }\end{array}$ & $\begin{array}{l}\text { Pencemaran Lingkungan/ } \\
\text { Environmental Pollution }\end{array}$ & $\begin{array}{l}\text { Perusakan \& pencurian } \\
\text { fasilitas prasarana tempat } \\
\text { pemeliharaan kapal/ } \\
\text { Vandalism and Stealing of } \\
\text { facilities infrastructure of where } \\
\text { vessels maintenance }\end{array}$ \\
\hline 4 & $\begin{array}{l}\text { Pengembangan Sarana \& } \\
\text { Prasarana Pengawasan \& } \\
\text { Pemantauan Kapal Perikanan/ } \\
\text { Development of Facilities } \\
\text { \&Surveillancelnfrastructure } \\
\text { \&SurveillanceFishing Vessels }\end{array}$ & $\begin{array}{l}\text { Penolakan penduduk } \\
\text { setempat/ Rejection of local } \\
\text { people }\end{array}$ & $\begin{array}{l}\text { Bentrokan fisik antara } \\
\text { penduduk dan aparat/ Physical } \\
\text { clashes between inhabitants } \\
\text { and officers }\end{array}$ \\
\hline 5 & $\begin{array}{l}\text { Penyelesaian Tindak Pidana } \\
\text { Kelautan \& Perikanan/ } \\
\text { Completion Criminal Acts of } \\
\text { Marine \& Fisheries }\end{array}$ & $\begin{array}{l}\text { Pelanggaran batas wilayah/ } \\
\text { Boundary violations }\end{array}$ & $\begin{array}{l}\text { Konflik terhadap aparat di } \\
\text { lapangan \& pengadilan/ } \\
\text { Conflict between officers in the } \\
\text { field and court }\end{array}$ \\
\hline
\end{tabular}

Sumber: diolah dari berbagai informasi dan pendapat.

Source : processed from a variety of information and opinions 
Pemerintah perlu melakukan tindakan hukum dengan menindak setiap pelanggar yang mengambil sumber daya perikanan secara tidak bertanggung jawab dan tanpa ijin. Luasnya wilayah perarian yang dimiliki Indonesia dan sumber daya manusia , menyebabkan sampai saat ini masih banyak pelanggaran di dalam memanfaatkan sumber daya perikanan. Keadaan ini dapat disikapi dengan adanya dukungan swakarsa penduduk setempat dalam wilayah demografi pengawasan. Koordinasi ini diperlukan untuk mencegah atau mengurangi adanya pelanggaran batas wilayah dan pemanfaatan sumber daya perikanan.

Pengawasan terpadu dan konsisten sangat memerlukan biaya operasional besar, yang sebaiknya dianggarkan khusus oleh pemerintah. Apabila tidak dianggarkan secara khusus, dapat menyebabkan sarana dan prasarana yang dijadikan sebagai alat transportasi dalam mengawasi perairan tidak terurus kondisi dan perawatannya. Pengawasan secara terpadu dapat memberikan dampak positif dalam meningkatkan perkonomian, karena porsi kekayaan sumber daya perikanan tidak berkurang akibat diambil oleh kapal-kapal berbendera asing.

Kegiatan peningkatan operasional pengawasan sumber daya kelautan mempunyai ancaman faktual keamanan dalam pelanggaran geografis batas wilayah Indonesia oleh kapalkapal asing. Pelanggaran batas wilayah ini, memerlukan dukungan political will pemerintah sebagai pengambil kebijakan untuk dapat memberikan ketegasan dalam menentukan batas wilayah perairan. Tanpa adanya ketegasan dapat menyebabkan terganggunya hubungan dengan negara lain, terutama yang berkaitan dengan pertahanan.-

Banyaknya kapal asing yang masuk tanpa ijin di wilayah perairan berpotensi merusak lingkungan perairan laut Indonesia. Limbah yang dihasilkan kapal asing di wilayah perairan Indonesia dapat menyebabkan kerusakan ekosistem yang dapat mengganggu kehidupan sumber daya perikanan di laut. Untuk mencegah hal tersebut maka setiap pelanggaraan harus ditindak secara hukum dengan memberikan sanksi tegas kepada setiap pelaku, untuk memberikan rasa jera. Pengawasan wilayah laut yang sangat luas juga tidak cukup hanya mengandalkan tenaga lapangan yang dimiliki pemerintah, namun membutuhkan bantuan penduduk yang tinggal di wilayah yang berdekatan dengan teritorial batas pengawasan. Berjalannya operasional pengawasan yang berkelanjutan dan konsisten membutuhkan dana yang tidak kecil. Dana juga diperlukan untuk biaya perawatan sarana dan menambah armada transportasi serta biaya operasional pengawasan. Dampak yang ditimbulkan dapat membantu mengurangi potensi kerugian dan bahkan berpotensi menambah devisa negara dan meningkatkan perekonomian di bidang sumber daya kelautan.

Salah satu kegiatan dalam program Ditjen P2SDKP adalah peningkatan operasional dan pemeliharaan kapal pengawas. Kegiatan ini berpotensi mendapat ancaman keamanan faktual terhadap perusakan dan pencurian kapal, sarana dan prasarana kapal dan tempat pemeliharaan. Perusakan dan pencurian dapat dilakukan oleh penduduk di wilayah operasional dan pemeliharaan kapal pengawas, akibat kesalahan manajemen ataupun adanya pelanggaran terhadap hak penduduk. Pelanggaran hak penduduk tersebut dapat disebabkan oleh arogansi pemerintah yang menjadikan hukum sebagai alat kekuasaan dalam memaksakan kehendaknya, tanpa mempertimbangkan keadilan dan hanya untuk kepentingan golongan saja.Potensi kerawanan gangguan dengan adanya kegiatan ini adalah pencemaran lingkungan yang diakibatkan limbah sampah dan industri yang dihasilkan oleh tempat pemeliharaan kapal pengawas.Dampak keamanan juga dapat ditimbulkan oleh sarana dan prasarana transportasi yang tidak mendukung dalam menunjang kinerja kelancaran operasional pemeliharaan kapal pengawas.

Kegiatan ini memerlukan dukungan politik pemerintah untuk mengawal dan memberikan anggaran khusus. Hal ini sangat diperlukan karena pemeliharaan kapal pengawasan membutuhkan dana yang tidak sedikit dan dilakukan secara berkala. Semakin banyak armada kapal pengawasan yang membutuhkan perawatan, maka semakin besar pula biaya yang harus dikeluarkan. Ancaman faktual keamanan yang berpotensi pada kegiatan pengembangan sarana dan prasarana pengawasan serta pemantauan kapal adalah bentrokan fisik antara penduduk dan aparat.

Salah satu potensi pemicu bentrokan sosial adalah penggunaan tanah masyarakat yang digunakan sebagai wilayah pengembangan sarana dan prasarana pengawasan. Ketidaksepakatan diantara masyarakat dan pemerintah berpotensi menimbulkan gangguan keamanan karena masyarakat tidak menginginkan wilayah tempat 
tinggalnya dibangun sarana pengembangan. Pembangunan sarana yang tidak sesuai dengan kebutuhan juga dapat menyebabkan pencemaran, berupa limbah sampah dan lainnya yang merusak lingkungan wilayah pengembangan sarana.

Kegiatan pengembangan sarana dan prasarana pengawasan serta pemantauan kapal, sangat memerlukan kesiapan dana dalam pelaksanaannya. Dana ini juga diperlukan untuk menambah kapal maupun menyediakan anggaran untuk menyewa kapal.Hal ini berhubungan dengan lingkup politik antara pemerintah pusat dan daerah yang masing-masing memiliki kepentingan yang mungkin berbeda, sehingga dikhawatirkan dapat menyebabkan dampak pengaturan kewenangan hukum dalam pengembangan wilayah berbeda.

Potensi kerawanan gangguan terhadap kegiatan penyelesaian tindak pidana kelautan dan perikanan adalah pelanggaran wilayah geografis terhadap batas wilayah perairan. Pelanggaran ini disebabkan kurangnya pengawasan maupun ketidak-tegasan pemerintah di dalam menentukan batas maupun menindak pelanggar dengan sanksi tegas. Salah satu faktor ketidaktegasan ini dapat diakibatkan adanya kerjasama aparat penegak hukum dari hulu hingga hilir yang dapat merugikan pemerintah dalam bidang ekonomi, yaitu dengan berkurangya pendapatan negara.

Penyelesaian sengketa atau perkara sangat memerlukan dukungan politik pemerintah dalam melaksanakannya, karena dapat menimbulkan akibat terhadap pertahanan negara.Hal ini dapat dimungkinkan apabilaterjadiklaimatas batas wilayah maupun ketidaktegasan dan/atau ketidakadilan dalam pemberian sanksi terhadap pelanggar. Bentrokan sosial juga dimungkinkan antara penduduk dengan aparat, karena ketidakadilan, ketidak tegasan, maupun kecurangan dalam penegakan hukum.

\section{PENUTUP}

Kegiatan yang tercakup dalam program pengembangan dan pengelolaan perikanan tangkap terdapat potensi gangguan dan ancaman faktual mulai dari konflik antar kelompok masyarakat hingga gangguan dari adanya kapal asing. Ancaman faktual keamanan dari kegiatan pengelolaan sumberdaya ikan adalah adanya potensi konflik antar kelompok masyarakat dan pelanggaran batas wilayah. Potensi konflik pada kegiatan pengelolaan sumberdaya ikan tersebut dapat terjadi baik antar masyarakat dalam satu wilayah propinsi yang terjadi antar kabupaten, ataupun antar wilayah pengelolaan perikanan yang satu dengan yang lainnya. Pelanggaran batas wilayah terjadi antar negara dan antar kabupaten atau propinsi, yang menjadi potensi kerawanan atau gangguan. Disamping itu, terdapat pula potensi konflik penggunaan alat tangkap dan gangguan kapal asing. Konflik penggunaan alat tangkap dapat terjadi antar masyarakat nelayan yang melakukan usaha penangkapan ikan.

Luasnya wilayah perarian yang dimiliki Indonesia dan sumber daya manusia, menyebabkan masih banyaknyaterjadi pelanggaran dalam pemanfaatan sumber daya perikanan.Keadaan ini dapat disikapi dengan adanya dukungan penduduk setempat dalam melakukan pengawasan. Pengawasan terpadu dan konsisten sangat memerlukan biaya operasional besar, yang sebaiknya dianggarkan khusus oleh pemerintah. Pengawasan secara terpadu dapat memberikan dampak positif dalam meningkatkan perkonomian, karena porsi kekayaan sumber daya perikanan tidak berkurang akibat adanya kegiatan penangkapan ikan yang illegal.Kegiatan peningkatan operasional pengawasan sumber daya kelautan mempunyai ancaman faktual keamanan dalam pelanggaran geografis batas wilayah Indonesia oleh kapal-kapal asing. Pelanggaran batas wilayah ini, memerlukan political will pemerintah sebagai pengambil kebijakan untuk dapat memberikan ketegasan dalam menentukan batas wilayah perairan. Tanpa adanya ketegasan menimbulkan hubungan dengan negara lain yang berkaitan dengan pertahanan dapat terganggu.

Perlu adanya kegiatan yang sifatnya mengantisipasi potensi gangguan dan ancaman faktual mulai dari konflik antar kelompok masyarakat hingga gangguan dari adanya kapal asing serta pelanggaran batas wilayah. Perlu pula diantisipasi konflik pada kegiatan pengelolaan sumberdaya ikan antar masyarakat dalam satu wilayah propinsi yang terjadi antar kabupaten melalui sosialisasi pengaturan pengelolaan perikanan pada suatu wilayah tertentu atau antar wilayah, termasuk pembatasan penggunaan alat tangkap. Selain itu juga diperlukan peningkatan partisipasi masyarakat dalam pengawasan sumberdaya kelautan dan perikanan dalam bentuk kelompok masyarakat pengawas (Pokwasmas). 


\section{DAFTAR PUSTAKA}

Dunn, W. N. 2000. Pengantar Analisis Kebijakan Publik. Edisi Kedua. Gadjah Mada University Press. Yogyakarta. 687 hal.

KKP (Kementerian Kelautan dan Perikanan), 2010. Peraturan Menteri Kelautan dan Perikanan Republik Indonesia Nomor PER.06/ MEN/2010. tentang Rencana Strategis Kementerian Kelautan dan Perikanan 2010-2014. Kemanterian Kelautan dan Perikanan. Jakarta. 84 hal.

Nazir, M. 1988. Metode Penelitian. Penerbit Ghalia Indonesia. Jakarta.
POLRI (Kepolisian Republik Indonesia), 2010. Bahan Paparan AMDAK (Analisis Mengenai Dampak Keamanan). Pusat Penelitian dan Pengembangan POLRI. Jakarta. 5 hal.

Simatupang, P. 2003. Analisis Kebijakan: Konsep Dasar dan Prosedur Pelaksanaan. Analisis Kebijakan Pertanian. . I (1): 14-35. Pusat Penelitian dan Pengembangan Sosial Ekonomi Pertanian. Badan Penelitian dan Pengembangan Pertanian. Departemen Pertanian. 


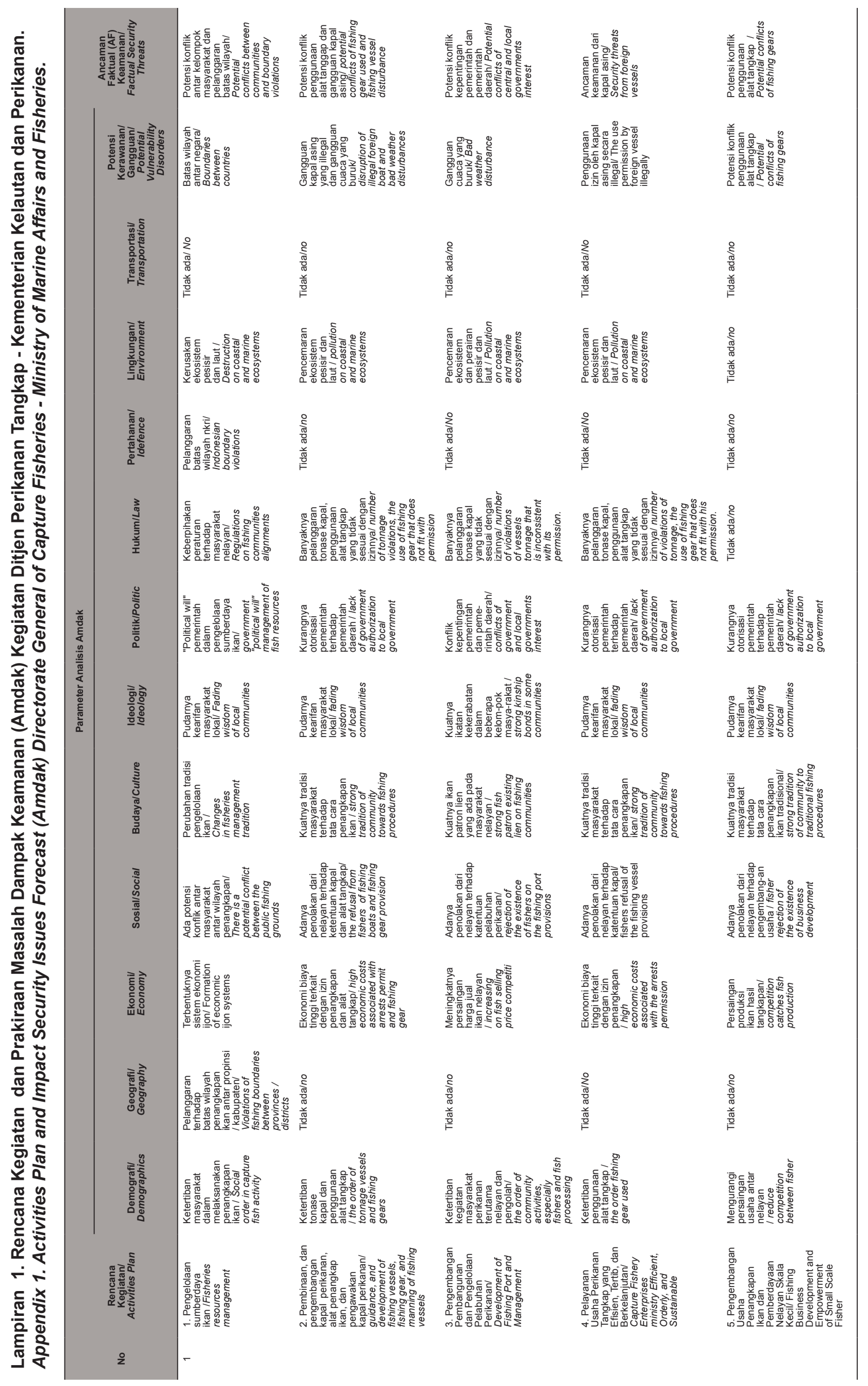

